\title{
ABSTRAK \\ PENERAPAN STRATEGI TEAM BUILDING DALAM MENINGKATKAN HASIL BELAJAR SISWA KELAS VIII PADA KOSEP EKOSISTEM DI SMPN 2 BATANG SUL-SEL
}

\author{
Suhaedir Bahtiar, Guru Bidang Studi Sains Biologi \\ SMP Negeri 2 Batang Jeneponto Sulawesi Selatan \\ 081342043867, E-mail: subha_3g@gmail.com
}

\begin{abstract}
Penelitian ini dilaksanakan selama 1 bulan yang dimulai pada bulan Oktober sampai November 2013. Tujuan penelitian untuk mengetahui penerapan strategi Team Building dapat meningkatkan hasil belajar siswa pada mata pelajaran Sains konsep ekosistem di Kelas VIII SMPN 2 Batang dengan subjek penelitian sebanyak 40 orang siswa. Hasil penelitian menunjukkan bahwa penggunaan strategi team building dapat meningkatkan hasil belajar materi ekosistem pada siswa kelas VIII di SMPN 2 Batang. Berdasarkan data yang diperoleh yakni; pada siklus I, hasil tes akhir siklus menunjukkan 37,5\%, siklus II 52,5\% dan siklus III 75\% siswa mencapai KKM.
\end{abstract}

kata kunci : team building, hasil belajar

\begin{abstract}
APPLICATION of STRATEGY TEAM BUILDING in ENHANCING STUDENT LEARNING OUTCOMES GRADE VIII On ECOSYSTEM CONCEPTS in SMPN 2 BATANG SUL-SEL

This research was carried out for 1 month which began in October and November 2013. The purpose of research to determine the application of the strategy team building can improve student learning outcomes on the concept of ecosystem in class VIII SMPN 2 Batang with the subject as many as 40 students. The results showed that use of the strategy team building can improve the learning results content ecosystem on a grade VIII in SMPN 2 Batang. Based on the data obtained: in cycle I, the end of the cycle test results showed $37,5 \%$; cycle II is $52,5 \%$; and cycle III is $75 \%$ of students achieving the KKM
\end{abstract}

keywords: team building, learning outcomes 
Upaya untuk mengatasi kesulitan belajar dan meningkatkan mutu pendidikan sekolah diantaranya adalah dengan menerapkan strategi pembelajaran yang baru. Strategi pembelajaran adalah cara yang digunakan oleh guru dalam proses belajar mengajar dengan berbagai variasi sehingga siswa terhindar dari rasa bosan dan tercipta suasana yang nyaman dan menyenangkan (Djamarah, 2006). Dalam interaksi belajar mengajar terdapat berbagai macam strategi pembelajaran yang bertujuan agar proses belajar mengajar dapat berjalan dengan baik. Hal ini juga bertujuan untuk menciptakan proses belajar mengajar secara menyeluruh (Mulyasa, 2008).

Gaya belajar merupakan kunci untuk mengembangkan kinerja dalam pekerjaan dan dalam situasi-situasi pribadi seperti memahami teman dalam proses belajar. Guru harus menyadari bahwa setiap orang mempunyai cara yang optimal dalam mempelajari informasi baru dan beberapa siswa perlu diajari cara-cara yang lain dari strategi mengajar (Usman, 2005). Mengetahui gaya belajar yang berbeda ini membantu guru untuk dapat mendekati semua atau hamper semua muridnya dengan menyampaikan informasi dengan gaya yang berbeda (Minarni, 2009).

\section{METODE PENELITIAN}

\section{Jenis Penelitian}

Jenis penelitian yang digunakan adalah penelitian tindakan kelas (PTK), maka pelaksanaan penelitian ini meliputi perencanaan, pelaksanaan tindakan, pengamatan, dan refleksi. Desain penelitian yang digunakan adalah model penelitian tindakan kelas yang dikembangkan oleh Kammis dan Taggart, mereka menggunakan empat komponen tindakan yang terdiri dari perencanaan, tindakan, observasi dan refleksi.

\section{Lokasi dan Waktu Penelitian}

Lokasi yang digunakan untuk pelaksanaan Penelitian ini adalah SMPN 2 Batang Sul-Sel dan dilaksanakan selama 1 bulan terhitung sejak bulan Oktober 2013.

\section{Subyek Penelitian}

Subyek dalam penelitian ini adalah siswa kelas VIII yang berjumlah 40 orang yang masih aktif belajar di SMPN 2 Batang tahun pelajaran 2013/2014. Bersumber dari hasil yang diperoleh melalui hasil pree test, siklus I, dan siklus II yang mencerminkan pemahaman siswa dengan konsep ekosistem yang di ajarkan, dengan penerapan strategi team building, diharapkan adanya peningkatan siswa dengan nilai yang ditetapkan secara individual yaitu 65 sedangkan untuk klasikal 70, yang sudah termasuk dalam kriteria ketuntasan mengajar (KKM). 


\section{Prosedur Penelitian}

Siklus I

1. Perencanaan

a. Identifikasi masalah dan penetapan alternatif pemecahan masalah.

b. Membuat rencana pelaksanaan pengajaran, media pembelajaran, dan semua perangkat pengajaran yang akan digunakan sesuai dengan metode yang dipergunakan berdasarkan pokok bahasan yang dipelajari.

c. Membuat lembar observasi untuk mengamati proses pembelajaran selama penerapan tindakan, yang meliputi minat, motivasi, dan keaktifan belajar siswa.

d. Menyusun tes untuk mengukur hasil belajar siswa selama tindakan penelitian diterapkan.

2. Tindakan

a. Menyampaikan indikator pembelajaran dan memotivasi siswa. Guru menyampaikan semua indikator pelajaran yang ingin dicapai dan memotivasi siswa untuk belajar.

b. Mengorganisasi siswa dalam kelompok-kelompok belajar. Setiap kelompok terdiri dari 4 orang siswa

c. Guru menyajikan informasi kepada siswa dalam bentuk metode ceramah dengan menggunakan LKS (Lembar Kerja Siswa). d. Siswa mendengarkan penjelasan guru tentang materi yang dipelajari.

e. Siswa berdiskusi dengan teman kelompok untuk membahas masalah (kasus) yang sudah dipersiapkan oleh guru.

f. Guru menunjuk secara acak kelompok yang akan presentasi menjelaskan konsep yang sedang dipelajari dengan menggunakan media atau alat peraga.

g. Evaluasi. Guru mengevaluasi hasil belajar tentang materi yang telah diberikan kepada masing-masing siswa.

h. Memberikan penghargaan. Guru mencari cara-cara untuk menghargai baik upaya maupun hasil belajar individu dan kelompok, misalnya guru mengacungkan jempol jika siswa menjawab atau mempresentasekan hasil diskusinya secara tepat.

3. Pengamatan

a. Melakukan observasi terhadap pelaksanaan tindakan saat pembelajaran berlangsung dengan memakai format observasi yang sudah disiapkan.

b. Melaksanakan evaluasi untuk mengukur hasil belajar siswa sesudah diterapkan tindakan

c. Permintaan tanggapan siswa tentang pelaksanaan tindakan dengan menggunakan kuesioner yang telah 
disiapkan. Evaluasi dan Permintaan tanggapan dilakukan pada akhir setiap siklus.

4. Refleksi

a. Refleksi dilakukan berdasarkan hasil analisis data, baik data hasil observasi maupun data hasil evaluasi.

b. Memperbaiki pelaksanaan tindakan sesuai hasil evaluasi, untuk digunakan pada siklus berikutnya.

Siklus II

1. Perencanaan

a. Identifikasi masalah yang muncul pada siklus I dan belum teratasi maka dilakukan penetapan alternatif pemecahan masalah.

b. Menentukan indikator pencapaian hasil belajar.

c. Pengembangan program tindakan II.

2. Tindakan

Pelaksanaan program tindakan II yang mengacu pada identifikasi masalah yang muncul pada siklus I, sesuai dengan alternatif pemecahan masalah yang sudah ditentukan, antara lain melalui:

a. Guru melakukan apersepsi

b. Siswa diperkenalkan dengan materi yang akan dibahas dan tujuan yang ingin dicapai dalam pembelajaran. c. Guru mengorganisasi siswa dalam kelompok-kelompok belajar. Setiap kelompok terdiri dari 4 orang siswa

d. Guru menyajikan informasi kepada siswa dalam bentuk metode ceramah dengan menggunakan media atau alat peraga.

e. Siswa mendengarkan penjelasan guru tentang materi yang dipelajari.

f. Siswa berdiskusi dengan teman kelompok untuk membahas masalah (kasus) yang sudah dipersiapkan oleh guru.

g. Guru menunjuk secara acak kelompok yang akan presentasi menjelaskan konsep yang sedang dipelajari dengan menggunakan media atau alat peraga.

h. Evaluasi. Guru mengevaluasi hasil belajar tentang materi yang telah diberikan kepada masing-masing siswa.

i. Memberikan penghargaan. Guru mencari cara-cara untuk menghargai baik upaya maupun hasil belajar individu dan kelompok, misalnya guru mengacungkan jempol jika siswa menjawab atau mempresentasikan hasil diskusinya secara tepat.

3. Pengamatan (Observasi)

a. Melakukan observasi sesuai dengan format yang sudah disiapkan dan 
mencatat semua hal-hal yang diperlukan yang terjadi selama pelaksanaan tindakan berlangsung.

b. Menilai hasil tindakan sesuai dengan format yang sudah dikembangkan.

c. Permintaan tanggapan siswa tentang pelaksanaan tindakan dengan menggunakan kuesioner yang telah disiapkan. Evaluasi dan Permintaan tanggapan dilakukan pada akhir setiap siklus.

4. Refleksi

a. Melakukan evaluasi terhadap tindakan pada siklus II berdasarkan data yang terkumpul.

b. Refleksi dilakukan berdasarkan hasil analisis data, baik data hasil observasi maupun data hasil evaluasi

Pada siklus III dirancang sama halnya dengan siklus I dan II dengan konsep ekosistem, langkah-langkah yang akan dilakukan sama seperti siklus I dan II hanya dalam siklus III hal-hal yang dianggap masih kurang dalam siklus I dan II diperbaiki.

\section{Teknik Analisis Data}

Sesuai dengan jenis data yang akan dikumpulkan, maka analisis data penelitian dilakukan dalam dua macam, yaitu Analisis kualitatif diberlakukan pada data hasil observasi terhadap kegiatan pembelajaran yang dilakukan oleh guru. Sedangkan analisis kuantitatif diberlakukan pada data aktivitas belajar siswa setelah mengikuti proses belajar mengajar untuk setiap siklusnya.

\section{HASIL PENELITIAN}

\section{Siklus I}

Pada akhir siklus I dilaksanakan tes akhir siklus tentang sub materi pengertian ekosistem, ekologi sebagai ilmu, penggunaan istilah-istilah dalam ekologi dan komponenkomponen penyusun ekosistem. Soal tes berupa 10 soal dalam bentuk PG. Adapun hasil tes akhir siklus I dapat dilihat dalam tabel analisis berikut:

Tabel 1 Analisis Hasil Tes Akhir Siklus I

\begin{tabular}{|l|l|l|l|}
\hline Skor & Frekuensi & Persentase & Keterangan \\
\hline $\mathrm{x} \geq 70$ & 15 & $37,5 \%$ & Tuntas \\
\hline $\mathrm{x}<70$ & 25 & $62.5 \%$ & Belum Tuntas \\
\hline
\end{tabular}

Berdasarkan tabel 1 di atas I sudah mengalami peningkatan dari hasil menunjukkan bahwa sebanyak 15 siswa dari tes awal. Tetapi belum dikatakan berhasil 40 siswa yang mencapai nilai persentase ketuntasan $\geq 70$ atau sebesar $37,5 \%$ siswa karena belum $65 \%$ siswa mencapai KKM. mencapai KKM. Hal ini menunjukkan siklus

Siklus II

Pada akhir siklus dilaksanakan tes 
akhir siklus II tentang berbagai interaksi dalam ekosistem, rantai makanan, jaring-jaring makanan, dan piramida ekologi. Soal tes berupa soal uraian yang terdiri atas 5 item. Adapun hasil tes akhir siklus II dapat dilihat dalam tabel analisis berikut:

Tabel 2 Analisis Hasil Tes Akhir Siklus II

\begin{tabular}{|l|l|l|l|}
\hline Skor & Frekuensi & Persentase & Keterangan \\
\hline $\mathrm{x} \geq 70$ & 21 & $52.5 \%$ & Tuntas \\
\hline $\mathrm{x}<70$ & 19 & $47.5 \%$ & Belum Tuntas \\
\hline
\end{tabular}

Berdasarkan tabel 2 di atas Untuk lengkapnya hasil tes akhir siklus II

menunjukkan bahwa sebanyak 21 siswa dari 40 siswa yang mencapai nilai persentase ketuntasan $\geq 70$ atau sebesar $52,5 \%$ siswa mencapai KKM. Hal ini menunjukkan siklus II sudah mengalami peningkatan dari hasil siklus I, namun dikatakan belum berhasil karena belum 65\% siswa mencapai KKM.

\section{Siklus III}

Pada akhir siklus dilaksanakan tes akhir siklus III tentang materi daur biokimia. Soal tes berupa soal uraian yang terdiri atas 4 soal. Adapun hasil tes akhir siklus III dapat dilihat dalam tabel analisis berikut:

Tabel 3 Analisis Hasil Tes Akhir Siklus III

\begin{tabular}{|l|l|l|l|}
\hline Skor & Frekuensi & Persentase & Keterangan \\
\hline $\mathrm{x} \geq 70$ & 30 & $75 \%$ & Tuntas \\
\hline $\mathrm{x}<70$ & 10 & $25 \%$ & Belum Tuntas \\
\hline
\end{tabular}

Berdasarkan tabel 3 di atas, pembelajaran di kelas telah dilaksanakan menunjukkan bahwa sebanyak 30 siswa dari 40 siswa yang mencapai nilai persentase sesuai dengan yang diharapkan. Hal ini ketuntasan $\geq 70$ atau sebesar $75 \%$ siswa terlihat dari hasil observasi terhadap guru yang menunjukkan bahwa semua tahapan mencapai KKM. Untuk lengkapnya hasil tes akhir siklus III

Hasil observasi secara umum terhadap kegiatan dalam RPP telah dilaksanakan dengan baik. Refleksi ini dilaksanakan di akhir pertemuan siklus III (setelah kegiatan guru dan siswa dalam proses memperoleh nilai tes siswa). Secara umum, pembelajaran pada siklus III dikatan sudah mencapai tujuan yang diharapkan. Dimana sudah menunjukkan keterlaksanaan proses berikut:

Tabel 4 Jumlah Siswa yang Mencapai KKM

\begin{tabular}{|l|c|c|c|c|c|}
\hline \multirow{2}{*}{ Skor } & Tes & \multicolumn{2}{|c|}{ Tes Akhir } & \multirow{2}{*}{ Keterangan } \\
\cline { 3 - 5 } & awal & Siklus I & Siklus II & Siklus III & \\
\hline $\mathrm{x} \geq 70$ & 4 & 15 & 21 & 30 & Tuntas \\
\hline $\mathrm{x}<70$ & 38 & 25 & 19 & 10 & Belum tuntas \\
\hline Jumlah & 40 & 40 & 40 & 40 & \\
\hline
\end{tabular}

Berdasarkan tabel 4 di atas menunjukkan bahwa persentase pencapaian 
KKM terus mengalami peningkatan untuk tiap siklusnya, yakni dari tes awal sebesar 10 $\%$, siklus I sebesar 37,5\%, siklus II meningkat menjadi 52,5\%, dan siklus III juga terjadi peningkatan menjadi $75 \%$. Adapun peningkatan persentase pencapaian KKM pada tiap siklus dapat dilihat pada grafik berikut:

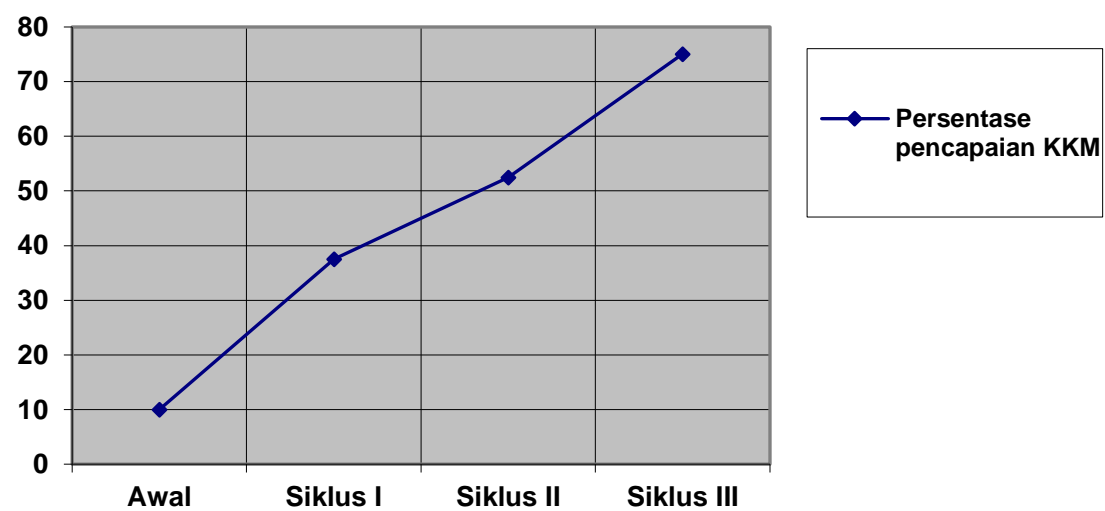

Dari hasil peningkatan ini lanjutan sesuai tahap-tahap siklus strategi menunjukkan bahwa strategi team building team building dengan tujuan meningkatkan yang diterapkan sudah dapat digunakan hasil belajar siswa.

dengan baik olah guru. Dengan demikian

Refleksi bertujuan untuk merefleksi dikatakan bahwa hipotesis tindakan telah perangkat pembelajaran, menganalisa tercapai yaitu dengan menerapkan strategi team building, hasil belajar ekosistem pada siswa kelas VIII SMPN 2 Batang dapat ditingkatkan.

\section{PEMBAHASAN}

Dari hasil tes awal menunjukkan ada 4 siswa dari 40 siswa yang mencapai nilai > 70 dengan persentase ketuntasan sebesar $10 \%$. Hal ini memberi gambaran bahwa hasil belajar biologi siswa kelas VIII SMPN 2 Batang pada materi ekosistem masih tergolong sangat rendah. Bertolak dari hasil tes awal maka peneliti, guru mata pelajaran dan teman sejawat merancang kegiatan kegiatan belajar mengajar yang berlangsung, sehingga menunjukkan kekurangan maupun kelebihan terhadap proses yang dilakukan agar ada upaya untuk memperbaiki kekurangan dan meningkatkan kelebihan tersebut guna memperoleh hasil yang lebih baik. Dalam kegiatan siklus I didapatkan hasil refleksi sebagai berikut:

\section{Aktivitas Guru}

Dari hasil observasi diketahui bahwa pada siklus I setelah dilakukan refleksi, guru belum melaksanakan pembelajaran sesuai RPP. Di mana dalam RPP yang dirancang memuat langkah-langkah kegiatan dan waktu 
dalam setiap kegiatan sudah ditentukan. Dengan harapan agar proses pembelajaran berjalan optimal dan tujuan pembelajaran dapat dicapai. Namun kenyataan pada pertemuan pertama, pembelajaran dilaksanakan tidak berdasarkan langkahlangkah dan waktu yang telah ditentukan, sehingga pembelajaran belum optimal dilakukan. Hal ini dapat terjadi karena guru belum menguasai RPP yang dibuat. Langkahlangkah yang tidak dilakukan yakni dikegiatan inti, guru tidak memandu siswa dalam berdiskusi antar kelomok untuk membahas hasil kerja kelompok.

Dari hal tersebut di atas, diperoleh beberapa kelemahan seperti; pada pertemuan pertama guru tidak menyampaikan tujuan pembelajaran kepada siswa. Selain itu guru lebih banyak memberikan kesempatan kepada siswa untuk berdiskusi sehingga penggunaan waktu tidak efektif juga belum memberikan kesempatan kepada siswa untuk membaca materi pada buku paket. Dalam menjelaskan materi di depan kelas masih terfokus pada sebagian siswa. Sehingga ada peluang bagi siswa yang lain bermain dan bercerita dan kurang serius mengikuti pembelajaran. Di sini guru kurang memperhatikan manajemen kelas, secara optimal. Guru hanya sibuk menerangkan dan terfokus pada kelompok yang dianggap aktif. Selain itu juga pada saat menjelaskan cara mengisi LKS terlalu cepat sehingga beberapa siswa mengalami kesulitan dalam mengerjakan LKS 01.

Kemudian guru juga belum optimal dalam memberikan dorongan kepada siswa untuk penyelidikan kelompoknya, bimbingan secara merata walaupun sudah berkeliling. Pengelolaan waktu juga belum optimal, sehingga LKS tidak sempat dibahas bersamasama bahkan ada kelompok yang tidak selesai mengerjakan LKS karena kehabisan waktu yang ditentukan.

2. Aktivitas Siswa

Strategi team building merupakan strategi pembelajaran dalam bentuk diskusi kelompok yang bukan baru bagi siswa, sehingga dalam pembelajaran ini tidak terdapat kekurangan dari siswa (Silberman, 2010). Namun siswa belum memperhatikan penjelasan guru, siswa kurang aktif dalam diskusi kelompok, siswa belum dapat menyampaikan pendapat pada saat materi pelajaran diajarkan.

Ada beberapa siswa belum mampu bekerja sama dalam kelompok, karena yang diharapkan dalam strategi team building salah satunya adalah bekerja sama dan pada kenyataannya anggota kelompok 4 dan 6 hanya satu siswa saja yang aktif. Perilaku yang tidak relevan, yaitu bercerita dan saling mengganggu, hal ini terjadi karena bimbingan guru belum optimal kepada setiap kelompok, karena masing-masing kelompok membutuhkan bimbingan dari 
guru pada waktu yang bersamaan.

Guru sudah memperbaiki kelemahan yang dilakukan pada siklus I dan sudah melaksanakan tindakan dengan baik sehingga ada peningkatan hasil belajar siswa dari tes sebelumnya. Dalam menjelaskan materi di depan kelas sudah memperhatikan pada semua kelompok. Dan kadang-kadang menghampiri siswa yang tidak memperhatikan pada saat menjelaskan. Guru juga dalam menjelaskan materi sudah bisa diikuti oleh siswa dengan baik. Upaya yang dilakukan guru adalah untuk mengoptimalkan kegiatan pembelajaran sehingga tujuan dapat dicapai.

\section{KESIMPULAN}

Penggunaan strategi team building dapat meningkatkan hasil belajar materi ekosistem pada siswa VIII SMPN 2 Batang. Berdasarkan data yang diperoleh yakni; pada siklus I, hasil tes akhir siklus menunjukkan $37,5 \%$, siklus II $52,5 \%$ dan siklus III $75 \%$ siswa mencapai KKM. Persentase pencapaian KKM terus mengalami peningkatan untuk tiap siklusnya.

\section{SARAN}

1. Bagi guru mata pelajaran, perlu meningkatkan pengetahuan tentang strategi team building yang sesuai dalam pembelajaran biologi, yaitu sesuai tidaknya dengan materi yang akan disampaikan, sehingga kegiatan belajar mengajar berjalan sesuai yang diharapkan.

2. Guru harus pandai memanajemen kelas, sehingga siswa tertib dan penggunaan waktu menjadi efektif dan efisien.

\section{DAFTAR PUSTAKA}

Budiningsi H. Asri. 2005. Belajar dan Pembelajaran. PT Rineka Cipta. Jakarta.

Departemen Pendidikan dan Kebudayaan RI. 1991. Kamus Besar Bahasa Indonesia Edisi Kedua. Balai Pustaka. Jakarta.

Djamara, Syaiful Bahri. 2006. Strategi Belajar Mengajar. PT Rineka Cipta. Jakarta.

Minarni. 2009. Upaya Peningkatan Hasil Belajar PKn Model Pembelajaran Problem Based Learning siswa kelas X MAN I Model kota Bengkulu. MAN I Model Bengkulu. Bengkulu.

Mulyasa, E. 2008. Menjadi Guru Profesional. PT Remaja Rosada Karya. Bandung.

Munthe, Bermawi. 2009. Desain Pembelajaran. PT Pustaka Insan Madani. Jogjakarta.

Pupuh dan M. Sobry, 2009. Strategi Belajar Mengajar. PT Rafika Aditama. Bandung.

Pribadi, Benny A. 2009. Model Desain Sistem Pembelajaran. Dian Rakyat. Jakarta.

Silberman dalam Silkia Puspita Kencana. 2010. Strategi Pembelajaran Inquiring Minds Want To Know (Menggali Pikiran Yang Ingin Tahu) Dan True Or False (Benar Atau Salah) Untuk Meningkatkan Hasil Belajar Biologi Pada Pokok Bahasan Keanekaragaman Hayati Pada Siswa Kelas X1 Man 1 
Surakarta. Skripsi. Universitas

Muhammadiyah Surakarta.

Surakarta.

Sudjana, Nana. 1996. Kurikulum di Sekolah.

Sinar Baru Algesindo. Bandung.

Suryosubroto, D. 1990. Dasar-dasar

Kependidikan. Rineka Cipta.

Jakarta.

Usman, Uzer. 2005. Menjadi Guru

Profesional. Remaja Rosdakarya.

Bandung 